\title{
Into the Unknown of Psychotherapy and Online Social Media
}

\author{
Kyle MacDonald
}

\author{
Registered Psychotherapist, AUCKLAND
}

\begin{abstract}
As psychotherapists we cannot avoid the significant impact and relevance of online social media to our thinking about relationships. This article discusses the world of online social media and its relationship to psychotherapy. The rise of and exponential increase in interactive online social media such as Facebook, Twitter, Linkedin and blogging have been collectively dubbed "Web 2.0." This term refers to the fact that the internet has become a user-interactive space for relating and, as such, increasing numbers of people are starting and maintaining personal and professional relationships online. The article provides a brief introduction to these terms, relevant websites, and the different uses and applications of these sites. Some relevant research into the effects of the use of social media on mood and experiences of social relationships is also included. Research in this field supports the idea that our online relating is consistent with our offline behaviour. The article concludes with some guidelines based on being a "participant observer" and psychotherapist.
\end{abstract}

\section{Whakarāpopoto}

Kāre e taea e tātou e ngā kaiwhakaora hinengaro te karo i te paanga me te hāngai o te hapori pāpāho ipurangi ki tā tātou aronga atu ki te whakawhanaungatanga. E matapakihia ana e tēnei tuhinga te ao o te hapori pāpāho ipurangi me tōna pānga atu ki te whakaoranga hinengaro. Ko te aranga, ā, te pikinga ake hoki o te hapori kōmitimiti pāpāho ipurangi pēnei i a Matapuka (Facebook), Tiotio (Twitter), Honomai (Linkedin), me blogging kua tapaina katoahia ēnei ko "Paetuku tuarua." E tohu ana tēnei kupu ki te meka kua riro te ipurangi ki tētahi àtea taumahitahi hai whakawhanaunga ā, nā tērā, ka rahi ake ngā tāngata e tīmata, e ū ana ki ngā mahi whakahoahoa ā-mahi, ā-whaiaro mā te ipurangi. He whakaaturanga poto tā tēnei tuhinga ki ngā kupu, ngā paetukutuku, me ngā tūmomo mahi katoa ā ēnei tauranga ipurangi. Kua whakaurua mai hoki ngā rangahau e hāngai ana ki te hua puta ake mai i ngā mahinga hapori pāpāho ki te whanonga me ngā wheako. Ko ngā rāngahau mai i tēnei āpure e tautoko ana i te ariā e rite ana ngā whanaungatanga

MacDonald, K. (2013). Into the unknown of psychotherapy and online social media. Ata: Journal of Psychotherapy Aotearoa New Zealand, 17(1), 65-72. DOI: 10.9791/ajpanz.2013.05 @ New Zealand Association of Psychotherapists Inc. 
ipurangi ki tērā whanonga o waho mai. E waiho ana ētahi aratohu i puta ake i te kaupapa "hoamahi kaititiro" me te kaiwhakaora hinengaro hai whakamutu ake i tēnei tuhinga.

Keywords: psychotherapy; social media; Facebook; Twitter; internet; blogging; online relating

\section{Introduction}

My name is Kyle MacDonald and I'm an internet addict. I spend a lot of time online. I feel anxious if I leave the house without my phone, which, basically, is a portable computer with more power than that on which I wrote my university essays. If I go to work or go away I take a laptop with me. However, the thing about being an internet addict is that it's not the "internet" to which I'm addicted, it's the access that it provides to the feeling of connection to other human beings all around the world; always to being involved in the flow of information about where my partner is; to what my friends in Australia are doing; to what the latest news is; to being able to read any newspaper in the world; and just to seeing what the weather forecast is before I leave the house.

What I'm addicted to is now collectively called "Web 2.0." This paper defines and explores the current state of Web 2.0, with a particular focus on the New Zealand context. I focus particularly on Facebook, Twitter and blogging, and briefly summarise some relevant research and writing about the qualitative experience of relating online via these media.

\section{Web 2.0}

The term "Web 2.0" (2004-present) is commonly associated with web applications that facilitate interactive information sharing, interoperability, user-centered design, and collaboration on the World Wide Web.... A Web 2.0 site allows its users to interact with other users or to change website content, in contrast to noninteractive websites where users are limited to the passive viewing of information that is provided to them. (Wikipedia, 2013d)

This way of interrelating and operating online has seen exponential growth which, in many ways, beggars belief. For example, from the time I first presented this paper at the 2010 NZAP Conference until now (2013), the number of members of Facebook has grown from 500 million to 1.01 billion (Associated Press, 2013). In raw numbers Facebook is now the third largest "country" in the world behind only India and China. One in every seven minutes spent online globally is spent on Facebook (Micklethwait, 2012).

Our local (national) picture is also dominated by Facebook and we can be considered to be a very "connected" country. The latest figures from December 2011 reveal that $89 \%$ of Kiwis use the internet, and $59 \%$ use it daily. $64 \%$ of internet users belong to a social media site and, of those, $96 \%$ state they use Facebook most often (Smith, Gibson, Crothers, Billot, \& Bell, 2011).

Research from 2010 (Curran, 2010) puts the number of Facebook members in New 
Zealand at 1 million. Based on these more recent figures this number can now be estimated to be closer to 2 million, or just under half our population.

\section{Facebook}

Much of the story of Facebook has now passed into myth, and now one also promulgated by Hollywood (see Fincher, 2010). Facebook began life in 2004 as a dorm room project by Mark Zuckerberg to create an online yearbook for Harvard students to keep in touch with what their friends were doing (see Wikipedia, 2013c). Initially it was restricted to Harvard, followed by other Ivy League schools (i.e. the universities of Brown, Columbia, Cornell, Dartmouth, Pennsylvania, Princeton, and Yale), then universities around the world and, finally, in February 2006, was opened to the general public to join. Core to its success was the "wall" on which, once users created an account and connected with the accounts of "friends", their own activity and posts automatically appeared, thus appearing on all their friends' pages. That Facebook placed relating and connectedness at its heart was the move that in many ways created the revolution we are now witnessing.

Facebook's strength has over time been its flexibility, that is, designing a platform that users can utilise to connect with others in ways in which they want. For example, you can make your posts public, private, linked to any online content, you can add images such as photos and choose with whom you share all these items. This model has undoubtedly worked, and has also attracted its fair share of critics, principally about privacy and the tension between Facebook pushing for more sharing in order to facilitate and grow the online community, versus users' desire for greater control over their own data.

\section{Blogging}

A blog (the short version of the term "weblog") is a website, usually maintained by an individual, with regular entries, much like a journal or collection of articles - see, for instance, my own on: www.psychotherapy.org.nz/off-the-couch. These entries or postings are usually arranged in reverse chronological order, displaying the most recent post first. There are a number of free services that enable people to create their own blogs easily.

Blogs span everything from being cutting-edge, public and leading journals, niche professional writing, humorous entertainment, and personal reflection. According to Nielsen (2012), at the end of 2011, the number of world-wide blogs numbered 181 million, though this is a hard figure to be accurate about due to the prolific growth of blogs and lack of a clear definition or a centralised way to track what constitutes a blog (see Wikipedia, 2013a).

The qualitative difference between journaling and writing a blog is the potential for an audience, even if none exists! The proliferation of blogs via free public platforms such as Wordpress and Blogger have also led to spin-off versions, such as so-called microblogging sites Tumblr and, of course, the other exponentially growing heavyweight of Web 2.0, Twitter.

\section{Twitter}

In essence, Twitter has combined the functionality of text messaging, by limiting its messages to 140 characters and the status update feature of Facebook into a "micro- 
blogging" platform e.g., "Twitter combines the functionality of txt messaging (up to a limit of 140 characters) and certain features of FcBk into a micro-blog platform”. Users connect with each other and post short public messages, links to content and photos, and have both public and private conversations to build connections and networks. As Evan Williams (2009), the co-founder of Twitter put it:

What we have to do is deliver to people the best and freshest most relevant information possible. We think of Twitter as it's not a social network, but it's an information network. It tells people what they care about as it is happening in the world. (in Williams \& Battelle, 2009)

At the end of 2012 Twitter had 640 million accounts, 72 million of which were daily active accounts, with users generating around 360 Twitters million per day (Wasserman, 2012).

Twitter acts as an amplifier, allowing interesting content to be reposted by followers who "retweet", and to promote others by mentioning them in their own tweets, thus advertising events. Of particular note with Twitter is both its speed and flexibility. It has been cited as an important influence in the publication of the recent Arab Spring (O'Donnell, 2011), and in allowing people on the ground to publish information and photos about the events. Its speed of response is such that many people (including myself) utilise it as their primary source of news and breaking news.

\section{Research}

So what do we know about how and why people relate online through these new technological media? Here I briefly summarise some of the research undertaken in this area, and advance the hypothesis that relating online is driven by the same need for connection as are all forms of human relating and, as such, is a valid area for psychotherapeutic inquiry. In line with this idea is the suggestion that people relate online in ways that are consistent with their offline behaviour.

One of the often cited pieces of research in the area of social media is the "Dunbar Number" (Wikipedia, 2013b). Robin Dunbar is an anthropologist whose research into primate social groups suggested that these social groups, which are maintained and formed via social grooming, are limited and proportional to the size of the neo-cortex. Ape groups tended to be a maximum of 55. Dunbar then theorised that, based on the proportional sizes of ape and human brains, human social groups should be no larger than 150 people. This has been dubbed the "Dunbar number" (Krotoski, 2010). Of ongoing interest to researchers is the question whether networking via platforms such as Twitter and Facebook increases our Dunbar number, or whether we need some other explanation to understand networks beyond this limit.

\section{Weak ties versus intimacy}

The concept of the Dunbar number explains the number of people we are capable of managing in a social network, that is, the people we consider friends or with which we 
have actual connections. However, once follower lists, and "friends' lists" go past this number we start to enter the territory of what sociologists term "weak ties" or what we might anecdotally label "acquaintances".

This rapid growth of weak ties can be a very good thing. Sociologists have long found that "weak ties" greatly expand your ability to solve problems. For example, if you're looking for a job and ask your friends, they won't be much help; they're too similar to you, and thus probably won't have any leads that you don't already have yourself. Remote acquaintances will be much more useful, because they're farther afield, yet still socially intimate enough to want to help you out. (Thompson, 2008)

\section{Online relating: Mood and consistency}

Given the nature of social media and, I would suggest, human nature, it has always seemed inevitable to me that people's online behaviour would be consistent with their offline behaviour. Anecdotally it has been my experience that this supposition is true. So are people "themselves" online? Initial research findings seem to suggest that, unavoidably, we are.

A study by Buffardi and Campbell (2008) found that untrained strangers were just as good at identifying narcissists from their Facebook page as they are at judging the personality of their actual "offline" friends. The kinds of things that lead people to make these accurate judgements were: a large number of contacts, a glamorous appearance, and a staged quality to the main photo. What is unclear from the research is the casual direction, that is: does using social media make people more narcissistic or is it simply a "stage" for those already inclined this way to use? Either way, these early results of Buffardi and Campbell (2008) tend to suggest that we can consider people's online behaviour as a valid realm for psychotherapeutic enquiry.

Initial psychological research into internet usage and mood was often framed negatively and generally dismissed online socialising as lonely escapism from the disquiet of "real" relationships. However, in 2006, a study by Campbell (2006) clarified that time spent online was actually unrelated to increased anxiety or depression, both of which were measured as markers of loneliness. In fact, only those who already showed lowered mood and anxiety and those who were already lonely were negatively affected.

Further, more subtle studies (e.g., Freberg, 2009) have shown that those who are well connected benefit from being online, and those who are already lonely feel lonelier. Lampe (2007) has also found that use of Facebook among college students was strongly correlated to an increase in social capital and subsequent increases in self-esteem. Furthermore, it appears that positive effects are strongest and most lasting for adolescents.

Recently, blogging has also been shown to have positive effects upon teenagers' moods; Meyran Boniel-Nissim and Azy Barak (2011) demonstrated that, of a group of 15 year olds with some level of social anxiety and stress, those that blogged about their struggles improved more than those who simply wrote in journals or did no writing.

These results go a long way to contradict the stereotype of the depressed teenager locked in dark room, "addicted" to their computer and avoiding the world. Indeed it suggests that prudent and intentional use of online social media may alleviate and even 
treat social distress. There is no doubt that these results should stimulate our interest as psychotherapists.

\section{Conclusions and Some Suggestions for the "Digital Immigrant"}

Teenagers of today have been dubbed "digital natives", having grown up in a world where the internet has always existed. Similarly, enthusiastic older users like myself have been referred to as "digital immigrants", that is, fairly acculturated and enthusiastic adopters of the social media and new technologies but missing the experience of growing up with them always there.

My experience is that through engagement with Facebook, Twitter and blogging in particular, my life, how I interact with others and with information feels unalterably changed in ways that are largely positive. My connections with others reflect the qualitative descriptions of both strong and weak ties, and I greatly enjoy each, and the networks in which I find myself travelling. From these modest travels, and from the research cited above I would like to conclude with a brief travel guide: a set of suggested guidelines for the use of social media by psychotherapists.

\section{Facebook}

- Study your privacy settings.

- Make your profile fully private (visible only to "friends") and only to people you actually know.

- Restrict your "friends" to people with which you actually socialise and have socialised.

- Keep your number of "friends" modest, i.e. below 150.

- Engage! Share and interact with others, dive in and be yourself.

- If you want to have a professional presence on Facebook, create a fully public professional "page" and/ or use "Linkedin" (a professional and business oriented social network) to connect with colleagues and share your professional profile.

\section{Twitter}

- Twitter is public, so only say, write or share what you are happy for anyone, including clients, to read.

- Use search terms to find and follow those who share your interests.

- Create weak ties, build a wide network of people and "retweet" those you find interesting (as this builds social capital, namely the impression that you relate well and are generous online with others.)

- Follow those who follow you. (This also builds social capital.)

- Fly your flag. Share your beliefs, support causes and engage in politics.

- Engage! Talk directly to people and start conversations.

- Dip in and dip out. Twitter flows 24/7, take what you want and leave the rest.

- Allow the issue of whether clients "follow" you to be part of the therapeutic conversation, and discuss with them if they want you to follow them. 


\section{Kyle MaCDonALD}

\section{Blogging}

- Blogging is good for you!

- Find and read blogs that are related to topics in which you're interested. Actively follow and comment.

- Feel free to write a blog. Keep it professional, as your clients may read it, but experiment and see what it feels like to write to an audience.

- Use free platforms like Blogspot or Wordpress, or microblog on Tumblr.

- Encourage clients to write blogs, and if they already do discuss this with them, do they find it helpful and how?

Dive in, enjoy and connect. See you online!

\section{References}

Associated Press. (2013). Number of active users at Facebook over the years. Retrieved $24^{\text {th }}$ February, 2013, from http://bigstory.ap.org/article/number-active-users-facebook-overyears-3

Boniel-Nissim, M., \& Barak, A. (2011,12 ${ }^{\text {th }}$ December). The therapeutic value of adolescents' blogging about social-emotional difficulties. [Advance online publication]. Psychological Services. DOI: $10.1037 /$ aoo26664 .

Buffardi, L., \& Campbell, W. (2008). Narcissim and social networking sites. Personality and Social Psychology Bulletin. 34,1303-1313.

Campbell, A. J., Cumming, S., \& Hughes, I. (2006). Internet use by the socially fearful: Addiction or therapy? Cyberpsychology and Behavior, 9(1), 69-81.

Curran, C. (2010, $10^{\text {th }}$ January). Social media and labour. Retrieved 21:55, $24^{\text {th }}$ February, 2013, from http://blog.labour.org.nz/index.php/2010/01/10/social-media-and-labour/

Ellison, N., Steinfield, C., \& Lampe, C. (2007). The benefits of Facebook "friends": Social capital and college students' use of online social network sites. Journal of Computer Mediated Communication, 12, 1143-1168.

Fincher, D. (Director), (2010). Social network [Film]. New York, NY: Columbia Pictures.

Krotoski, A. (2010,14 ${ }^{\text {th }}$ March) Robin Dunbar: We can only ever have 150 friends at most. The Guardian. Retrieved 22:15, 17 February, 2013, from http://www.guardian.co.uk/ technology/2010/mar/14/my-bright-idea-robin-dunbar

Micklethwait, J. (2012, $4^{\text {th }}$ February). A fistful of dollars. The Economist, p. 9.

Nielsen. (2012, $8^{\text {th }}$ March). Buzz in the blogosphere: Millions more bloggers and blog readers. In Neilsen Wire. Retrieved 22:00, $24^{\text {th }}$ February, 2013, from http://blog.nielsen.com/ nielsenwire/online_mobile/buzz-in-the-blogosphere-millions-more-bloggers-and-blogreaders/

O’Donnell, C. (2011, September). New study quantifies use of social media in Arab Spring. Retrieved 21:45, $17^{\text {th }}$ February, 2013, from http://www.washington.edu/news/2011/o9/12/ new-study-quantifies-use-of-social-media-in-arab-spring/

Smith, P., Gibson, A., Crothers, C., Billot, J., \& Bell, A. (2011). The internet in New Zealand 2011. Institute of Culture, Discourse \& Communication, AUT University, Auckland, New Zealand. 
Thompson, C. (2008, $5^{\text {th }}$ September). Brave new world of digital intimacy. The New York Times. Retrieved 22:10, $24^{\text {th }}$ February, 2013, from http://www.nytimes.com/2008/09/07/ magazine/o7awareness-t.html?_r=2\&pagewanted=all

Wasserman, T. (2012, December). Twitter user ID numbers cross into the billions. Mashable. Retrieved 22:05, $24^{\text {th }}$ February, 2013, from http://mashable.com/2012/12/11/twitter-1billionth-user-id/

Wikipedia. (2013a). Blog [Entry]. Wikipedia, the free encyclopedia. Retrieved oo:3 $8,18^{\text {th }}$ February, 2013, from http://en.wikipedia.org/w/index.php?title=Blog\&oldid=538159967

Wikipedia. (2013b) Dunbar's number [Entry]. Wikipedia, the free encyclopedia. Retrieved oo:52, $25^{\text {th }}$ February, 2013, from http://en.wikipedia.org/w/index.php?title=Dunbar\%27s_ number\&oldid $=539595082$

Wikipedia. (2013c). Facebook [Entry]. In Wikipedia, the free encyclopedia. Retrieved 05:01, $20^{\text {th }}$ February, 2013, from http://en.wikipedia.org/w/index.php?title=Facebook\&oldid=539110704

Wikipedia. (2013d). Web 2.0 [Entry]. In Wikipedia, the free encyclopedia. Retrieved 21:57, $17^{\text {th }}$ February, 2013, from http://en.wikipedia.org/w/index.php?title=Web_2.o\&oldid=537791696 Williams, E., \& Battelle, J. (2009). A conversation with Evan Williams. In Web 2.o Summit o9. Retrieved 21:50, $24^{\text {th }}$ February, 2013, from http://www.youtube.com/ watch?v=p5jXcgZnEao\&fmt=18

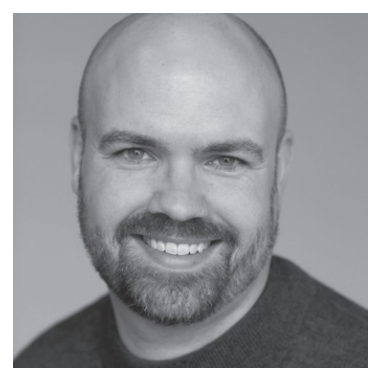

Kyle MacDonald trained at AUT University, graduating in 2001 and has a particular interest in psychodynamic therapies and Dialectical Behaviour Therapy (DBT), with a focus on Mindfulness-based approaches. He is a co-director of the Robert Street Clinic, established in 2010 as a private psychotherapy and counselling service in Ellerslie, Auckland. He currently divides his time between public and private practice, also working for the Segar House Intensive Day Programme, the Auckland District Health Board Specialist Psychotherapy Service. Since 2010 he has served as the NZAP representative to the ACC Sensitive Claims Advisory Group. He is currently serving on the NZAP's National Council and is Chair of Public Issues. He spends far too much time online and you can read his regular blog at www.psychotherapy.org.nz/off-the-couch, follow him on Facebook at www.facebook.com/psychotherapy.org.nz, or connect via Twitter: www.twitter.com/@kylemacd.

... and Kyle's Twitter biography:

"I like to help people | Psychotherapist | Director @Robertstclinic | Blogger | Regular guest Sunday a.m. @RadioliveNZ |” 